\title{
Suomalainen magiaperinne kognitiotieteellisestä näkökulmasta
}

\author{
Siria Kohonen
}

$\mathrm{M}$ istä puhumme, kun puhumme suomalaisesta magiaperinteestä? Magian määrittely on humanistisissa ja sosiaalitieteissä ollut varsinainen murheenkryyni etenkin viimeisen sadan viidenkymmenen vuoden aikana. Milloin magiaa on pidetty rationaalisuuden yhtenä ilmenemismuotona tieteen ja uskonnon rinnalla (esim. Tylor 1871; Frazer 1911), milloin yhteisön tai yksilöiden arvoja ilmentävänä toimintana (esim. Mauss 1972; Durkheim 1965). Toisaalta magiaa on myös pidetty erityisenä performatiivisena toimintana (esim. Malinowski 1935; Tambiah 1968) tai emootioiden kanssa vuorovaikuttavana ja niitä ilmentävänä käyttäytymisenä (esim. Freud 1981a ja 1981b; Marett 1979; Lévy-Bruhl 1985).' Suomalainen magian tutkimus on taas kulkenut käsi kädessä muun suomalaisen kansanperinteen tutkimuksen kanssa ja noudatellut sen tutkimusparadigmoja. ${ }^{2}$

Viime vuosikymmeninä suomalaisen varhaismodernin magian tutkimus on keskittynyt esimerkiksi suomalaiseen tietäjälaitokseen (esim. Siikala 1992), loitsujen rakentumiseen (esim. Piela 1983; 1989) tai taikuuden ja arkielämän yhtymäkohtiin (esim. Issakainen 2012). Yleisesti suomalaisen 1800-1900-lukujen magian määrittelyssä ja tutkimuksessa on tärkeässä roolissa ollut etnologi Laura Stark. Stark on tutkinut magiaa erityisesti sosiokulttuurisena ilmiönä (esim. 2006), ja hän on arvioinut emootioiden, esimerkiksi pelon ja vihan, suhteita magiaperinteeseen käsitellen näitä pikemminkin sosiaalisina konstruktioina kuin ilmiöinä, joilla olisi kehollinen tai evolutiivinen perusta (2016). Stark esittää, että nämä emootiot ovat varhaismodernissa suomalaisessa maalaisympäristössä linkittyneet vaarojen, itsesuojelun ja vahingoittamisen teemoihin ja että magia on ollut ihmisten tapa käsitellä näitä teemoja.

Tässä katsausartikkelissa esittelen, miten suomalaisen varhaismodernin magiaperinteen tutkimusta voi täydentää kognitiotieteellisellä lähestymistavalla. Stark ei esimerkiksi ota kantaa kysymyksiin, miksi emootiot liittyvät hänen listaamiinsa teemoihin, miten emootioiden liittyminen näihin teemoihin on verrattavissa muiden kulttuuriperinteiden vastaaviin ilmiöihin tai millaisin mekanismein perinnettä tuottavat ihmiset ilmentävät emootioita. Kognitiivinen

1 Kattava katsaus määritelmiin esim. Otto \& Stausberg 2013. Pätevä yleisesitys magian tieteenhistoriasta esim. Sørensen 2007, 9-30; Otto \& Stausberg (eds.) 2013.

2 Esimerkiksi maantieteellis-historiallista tutkimusotetta hyödynnettiin magian tutkimuksessa paljon (ks. esim. Krohn 1915), ja erityisesti kansanparannukseen liittyvää magian käyttöä on tutkittu performatiivisuuden kautta (ks. esim. Honko 1960). 
lähestymistapa kykenee pureutumaan näihin kysymyksiin, ja näin se täydentää aiempaa tutkimusta.

Kognitiotieteellinen näkökulma magian tutkimukseen keskittyy kysymyksiin siitä, mitä yksilön mielessä tapahtuu maagisten ilmaisujen yhteydessä ja miksi. Kognitiolähtöistä magiatutkimusta on kritisoitu siitä, että se jättää huomiotta kulttuuriset eroavaisuudet erilaisten magiaperinteiden välillä (esim. Stark 2006, 36-37). Tässä katsauksessa tarkoituksenani on esittää keinoja ymmärtää, miksi erilaisten ihmisten parissa ylipäätään esiintyy maagista ajattelua ja käyttäytymistä. Vaikka en nostakaan kulttuurisia eroavaisuuksia esille, en väitä, että näillä ei olisi yleisesti aiheen tutkimuksen kannalta merkitystä. Kognitiolähtöisen tutkimuksen avulla voidaan esimerkiksi arvioida sitä, mikä magiaperinteessä on tyypillistä erityisesti suomalaiselle kulttuurille ja mikä taas ylipäätään ihmisille.

Kognitiivinen tutkimus keskittyy siihen, miten ihmisen tiedonkäsittely tapahtuu mielessä. Tiedonkäsittelyn perusrakenteet ovat inmisillä samat, vaikka kulttuuriset syötteet täyttävätkin mielen toimintaa. Analogisesti voidaan kuvata, että kognitiiviset perusrakenteet ovat kuin joen uomat ja kulttuuriset syötteet ovat uomassa virtaavaa ja sitä täyttävää vettä. Ihmiset ajattelevat keskenään eri tavoin, mutta perusedellytykset ajattelulle ovat samat. Mielen perusrakenteet ovat muovautuneet ihmislajin evolutiivisen kehityksen aikana, satojen tuhansien vuosien aikahaarukassa, ja nämä perusrakenteet vaikuttavat ihmisen ajatteluun edelleen.

Tässä katsauksessa sovellan kognitiolähtöistä magiatutkimusta suomalaisen parannusmagian tutkimukseen. Aineistonani käytän Suomalaisen Kirjallisuuden Seuran perinteen ja nykykulttuurin kokoelman tekstejä palohaavojen parantamisesta. Aineisto on kerätty maaseudulta 1900-luvun alkupuolella, erityisesti 1930-luvulla, ja se koostuu sekä parantamisen ohjeistuksista että omakohtaisista kertomuksista parantamisesta. Tekstit eivät välttämättä esitä tarkkoja kuvauksia siitä, miten inmiset tosiasiassa ovat palohaavoja parantaneet, mutta ne välittävät lukijalle kulttuurista tietoutta tästä kontekstista: mitä parannetaan, miksi ja miten. Parantamiseen liittyvien mielikuvien sanallistamisten avulla voidaan lähestyä sitä, miten mielikuvat ovat mielessä syntyneet. Antamani esimerkit on valittu kuvaamaan esittelemieni teorioiden soveltamista mahdollisimman selkeästi, joten nostan esimerkeistä esiin vain tiettyjä teoriaa tukevia puolia, mutta samoja esimerkkejä voidaan myös käsitellä laajemmin, useampien teorioiden valossa.

Keskeisiä käsitteitäni tässä katsauksessa ovat magia, maaginen ajattelu ja ritualisoitunut käyttäytyminen. Pidän näitä toistensa lähikäsitteinä. Magia on käsitteistä epämääräisin: sen alle voidaan lukea ainakin

1. magian harjoitus käytännössä (esimerkiksi pyrkimykset muuttaa välitöntä kokemusmaailmaa vaikuttamalla asioihin, joiden koetaan kuuluvan transsendenttiin todellisuuteen, kuten henkiolentoihin),

2. taikoihin liittyvät tarvikkeet ja performanssit,

3. ilmiöt, jotka vaikuttavat magian harjoittamiseen, sekä

4. ajatuslogiikka, johon käytännön taikojen tekeminen perustuu, eli maaginen ajattelu. 
Maaginen ajattelu viittaa ajatteluun ja päättelyyn, joka ilmenee maagiseksi luokiteltujen tekojen tekemisessä mutta jota tapahtuu myös arkielämässä taikojen ulkopuolella. Maagista ajattelua ilmenee myös uskonnollisessa elämässä, jota inmiset itse eivät usein miellä maagiseksi. $^{3}$

Maagista ajattelua esiintyy myös ritualisoituneessa käyttäytymisessä. Rituaalitutkimuksessa ritualisoitumiselle on erilaisia määritelmiä, jotka painottuvat tutkimusnäkökulman mukaan (ks. esim. Grimes 2014). Tässä artikkelissa tarkastelen ritualisoitunutta käyttäytymistä käyttäytymismuotona, jota ihmiset alkavat helposti noudattaa evolutiivisesti merkittävissä stressaavissa tilanteissa, esimerkiksi kun ruokaresurssit, selviytyminen tai oma jälkikasvu ovat uhattuina (ks. esim. Boyer \& Liénard 2006). Ritualisoitunutta käyttäytymistä esiintyy uskonnollisissa rituaaleissa ja taikojen tekemisessä, mutta myös näiden ulkopuolella.

Käsittelen ensin maagisen ajattelun mekanismeja ja näiden ilmenemistä suomalaisessa parannusmagiassa. Esittelen tältä kannalta kaksi teoriaa, jotka ovat oleellisia maagisen ajattelun muotoutumisessa: psykologisen olemusajattelun ja käsitteellisen sekoittumisen teorian. Kolmanneksi käsittelen ritualisoitunutta käyttäytymistä ja sen suhdetta suomalaiseen parannusmagiaan.

\section{Maaginen ajattelu}

Kuvittele mielessäsi henkilö, jota inhoat yli kaiken. Ehkä tämä henkilö on joku, joka on loukannut tai häiriköinyt sinua, hyökännyt kimppuusi kovin sanoin tai jopa fyysisesti. Ehkä hän on alistanut sinua tai käyttänyt sinua hyväkseen. Sitten saat käsiisi hänen paitansa. Haluaisitko pukea sen päällesi?

1980-luvulla ja 1990-luvun alussa psykologit Carol Nemeroff ja Paul Rozin tutkimusryhmänsä kanssa suorittivat kokeita, joissa koehenkilöille esitettiin ylläolevan kaltaisia kysymyksiä (Rozin, Millman \& Nemeroff 1986; Rozin et al. 1989; Rozin \& Nemeroff 1990; Nemeroff \& Rozin 1994; Nemeroff \& Rozin 2000). Koehenkilöinä toimivat pääasiassa amerikkalaiset yliopisto-opiskelijat. Suuri osa kokeiden osallistujista koki epämiellyttävänä ajatuksen pukea ylleen paidan, joka oli kuulunut heidän inhoamalleen ihmiselle. Jotkut jopa perustelivat vastaustaan sanomalla, että heistä tuntui kuin paitaan olisi jäänyt jäljelle tämän henkilön inhottavuus (Nemeroff \& Rozin 1994, 178).

Tieteellinen keskustelu maagisesta ajattelusta on alkanut jo Tylorin ja Frazerin tutkimuksissa 1800-1900-lukujen vaihteessa. He väittivät, että maaginen ajattelu on primitiivistä ja luonnonläheisille kansoille tyypillistä. Frazer muotoili sympateettisen magian typologian: magia jakautuu samankaltaisuusmagiaan (law of similarity) ja tarttumismagiaan (law of contagion) (Frazer 1911). Samankaltaisuusmagia perustuu ajatukseen, jonka mukaan samanlaiset asiat vaikuttavat toisiinsa, ja tarttumismagian taustalla on ajatus, että kosketuksissa aiemmin olleet asiat ovat myöhemminkin vaikuttavassa yhteydessä toisiinsa.

Nemeroff ja Rozin esittivät, että maaginen ajattelu ei johdu luonnonläheisten kansojen kulttuurisesta tiedosta tai heidän mielensä toiminnasta, joka poikkeaisi moderneista länsimaisista ihmisistä. Maagista ajattelua esiintyy myös länsimaisten ihmisten mielessä. Kokeissa

3 Magian ja uskonnon suhteesta käytyä keskustelua tiivistää esim. Otto \& Stausberg 2013, 5-7. 
huomattiin maagisen ajattelun tiivis yhteys evoluution kannalta tärkeään kehitykseen: havaitessaan merkkejä vaarasta tai kokiessaan inhoa ihmisen on parempi välttää näiden aiheuttajia kokonaan pysyäkseen hengissä ja lisääntyäkseen. Vääriin hälytyksiin reagoiminen voimakkaasti on parempi kuin reagoimattomuus silloin, kun ihmisen henki on todella kyseessä, ja yleisesti ihmisillä on valmius oppia tällainen ajattelutapa helposti jo pienenä lapsena (Nemeroff \& Rozin 2000, 22-25).

Maagisen tarttumis- ja samankaltaisuusajattelun taustalla toimii mielen kaksijakoinen prosessointisysteemi. Mielen kaksoisprosessointiteorian (dual-process theory) mukaan ihmismieli toimii kahdella eri tavalla: on nopeaa intuitiivista ajattelua sekä hidasta reflektiivistä ajattelua (esim. Evans 2010; Kahneman 2011). Intuitiivinen ajattelu aktivoituu refleksinomaisesti ja esittää mieleen tulevista ärsykkeistä ensimmäiset päätelmänsä. Intuitiivisen ajattelun päätelmät perustuvat kognition rakenteisiin, esimerkiksi mielen skeemoihin, skripteihin ja kategorioihin, jotka ohjaavat ihmistä toimimaan tilanteissa tietyllä, opitulla tavalla tai luokittelemaan vastaantulevat ilmiöt tiettyihin ryhmiin. Näiden kognitiorakenteiden sisältö perustuu ihmisen aiempiin kokemuksiin ja hänen kohtaamiinsa ilmiöihin, ja sisältöjen muovautuminen jatkuu koko elämän ajan. ${ }^{4}$ Intuitiivista ajattelua on esimerkiksi tieto siitä, kuinka kassajonossa käyttäydytään, tai ensiajatukset siitä, minkälainen henkilö on italialainen pukumies. Intuitiivinen ajattelu helpottaa inmisen toimintaa, jotta hänellä ei kuluisi joka kerta aikaa esimerkiksi sen pohtimiseen, tarvitseeko italialainen pukumies ruokaa selvitäkseen hengissä tai osaako tämä juosta neljällä raajalla. Fyysisten piirteiden lisäksi intuitio saattaa tarjota esimerkiksi stereotyyppisiä kuvauksia italialaisten pukumiesten luonteesta.

Intuitiivista ajattelua seuraa reflektiivinen ajattelu. Tämä on hitaampi ajattelumalli, ja sen tarkoituksena on vahvistaa, korjata tai muuttaa intuitiivisen ajattelun päätelmiä (esim. Evans 2010; Kahneman 2011). Esimerkiksi italialaisen pukumiehen kohdatessaan reflektiivinen ajattelu todennäköisesti vahvistaa tiedon siitä, että kyseessä on intentionaalinen agentti ja fyysinen ihminen. Sen lisäksi reflektiivinen mieli saattaa vahvistaa intuitiivisen ajattelun stereotypiat miehen luonteesta tai sitten korjata niitä monipuolisemmiksi. Reflektiivinen ajattelu, varsinkin intuitiivisen ajattelun syötteiden korjaaminen, vaatii mieleltä ponnisteluja, eikä se ole yhtä automaattista kuin intuitiivinen ajattelu. Molemmat ajattelutavat toimivat kuitenkin jatkumona eikä niitä voi täysin erottaa toisistaan. Suurin osa tästä koko mielen ajatteluprosessoinnista tapahtuu tiedostamattomasti, ja intuitiiviset taustaoletukset pysyvät usein tiedostamattomina myös reflektiivisen ajattelun prosessoinnin jälkeen (Wegner 2002; Evans 2010, 6).

Maagiseen ajatteluun liittyy monia intuitiivisia olettamuksia ja ajatteluvinoumia (biases), joita reflektiivinen mieli myös vahvistaa (Pohjanheimo 2012, 300-301). Näistä maagiseen ajatteluun vaikuttaa ensinnäkin psykologinen olemusajattelu (psychological essentialism). Mielellä on taipumus olettaa, että tietyn kategorian, esimerkiksi italialaisten pukumiesten kategorian, kaikkia jäseniä yhdistää samankaltainen olemus, joka määrittää perinpohjaisesti, miksi jäsen kuuluu tähän kategoriaan (Medin 1989, 1476-1477; Gelman ym. 1994). Ajatus tällaisen olemuksen olemassaolosta yhdistettynä esimerkiksi juuri inhoemootioon tai

4 Toisaalta intuitiivinen ajattelu voidaan jakaa myös biologiseen ja opittuun (vrt. maturationally natural vs. practiced intuition; ks. esim. McCauley 2011). 
havaintoon vaarasta voi laukaista olettamuksen siitä, että tämä olemus kykenisi siirtymään kosketuksen välityksellä tai olemaan etäisyyksien päästä yhteydessä samaan olemukseen. ${ }^{5}$

Näitä mielen prosesseja ja niiden suhdetta kulttuurisiin representaatioihin voi analysoida esimerkiksi tarkastelemalla seuraavia tekstejä:

Tulen vihat

Tulen vihoiksi sannoit ennen sellaista tautii jos kipijä sai liikaa kuumuutta. Jos mänit saunaankii ja oli jokkuu kipijä, niin vanhat sannoit " paa jokkuu vaate päälle että ei käy tule (löyly) vihat", ja jos oli rupi tai haava, niin heti sanottii "älä mää tule luokse siihe käyvät tule vihat", se ärtyy ja (liitan) hellan päälle ei saant sylkiä, silloin tuli rokko huulee, kävivät tule vihat. Eikä saanut maitoakkaa laskea lietee lehmä tissit rokahtuut, siihe käyp tulen vihat, ja miun mummoin pan vasikan juotavaa tulisii hiiliä, se piti olla niinkuin lääkkeeksi, ja sijoille syöttiit hiiliä, ne oli terveellissii, ja pienille lapsillekkii antoit vanhat hiilen, jähtyneen kylmän hiilen liijestä kättee, se on terveellistä, sano miun mummoin aina.

(Koivisto. Ulla Mannonen 4992. 1937. Maija Stark 62v.)

Palanut

Palanutta kohtaa kastettiin kylmään veteen, johon oli sekoitettu kuumaa tuhkaa tai käärittiin palaneen ympärille pellavavaate, jota oli kastettu edellämainittuun tuhkaveteen. Auringon polttamaa voideltiin "voiheralla", s.o. keitetyllä voilla.

(Vuoksenranta. Aino Arponen E 114, s. 5-6. 1934. Maria Talja, os. Hartikainen, 64v.)

Tulen vihoja, samoin kuin muunlaisia haavoihin asettuvia "vihoja", on pidetty eräänlaisena tautina ympäri Suomea esi- ja varhaismodernina aikana. Vihojen on ajateltu kykenevän asettumaan avoimen ihon kautta ihmisen ruumiiseen, ja niitä on pidetty väen, dynaamisen transsendentin voiman, ikävänä esiintymismuotona (ks. esim. Stark 2006, 272-277).

Ensimmäinen esimerkki osoittaa, kuinka vihojen on ajateltu voivan siirtyä kipeään paikkaan lähietäisyyden kautta. Vihat kuvataan tekstissä ikään kuin ne olisivat alkuperäisen kantajansa olemuksen siirtymään kykenevä osa. Havainto vaarasta - tietous siitä, että kipeä tulee kipeämmäksi löylyissä - hälyttää mielen tulkitsemaan, että löylystä tai tulesta voi tarttua jotain vaarallista. Ajatus on psykologisen olemusajattelun ja siihen pohjaavan tarttumisajattelun mukainen.

Parannukseksi tai ennaltaehkäisyksi ehdotetut hiilet taas kuvaavat samankaltaisuusajattelua. On ajateltu, että hiilillä ja tulella on yhteinen olemus, joka saa ne vaikuttamaan toisiinsa. Yhteinen olemus ei kuitenkaan ole saanut ihmisiä välttelemään myös hiiliä tulen vaarallisuuden takia. Ihmisille on muodostunut kokemusperäistä tietoa kylmien tai veteen sekoitettujen hiilien vaarattomuudesta.

$5 \quad$ Toisaalta voidaan puhua myös olemuksen tietyistä tarttuvista osista tai piirteistä eikä välttämättä koko olemuksen siirtymisestä (ks. esim. Sørensen 2007, 105-106). 
Maagiseen ajatteluun vaikuttaa myös intuitiivinen käsitteellisen sekoittumisen prosessi (conceptual blending, blending theory). Tämä prosessi tukee mielen luovaa ajattelua. Käsitteellistä sekoittumista, esimerkiksi metaforien luomista, tapahtuu mielen kategorioiden välillä: kahden kategorian yhteisten piirteiden kartoituksista muodostuu uusi sekoittunut käsite. Teoria perustuu George Lakoffin ja Mark Johnsonin metaforateorian (esim. Lakoff \& Johnson 1980) sovelluksiin, joita ovat muotoilleet erityisesti Gilles Fauconnier ja Mark Turner (Fauconnier 1994, 1997; Turner 1996; Fauconnier \& Turner 2002). Mieli tuottaa sisältöä uudesta tuntemattomammasta tai abstraktista ilmiöstä lainaamalla siihen piirteitä kategorioilta, joita se tuntee paremmin ja konkreettisemmin. Esimerkiksi Lakoffin ja Johnsonin käyttämässä metaforassa elämä on matka tutumpaa käsitettä "matka" käytetään sen havainnollistamiseksi, mitä abstraktimpi käsite "elämä" tarkoittaa.

Suomalaisessa varhaismodernissa parannuskontekstissa toimii esimerkiksi metafora (tartunta)tauti on tunkeilija, jossa konkreettisempaa käsitettä tunkeilija käytetään taudin käsittelemiseen. Tunkeilija-metaforaa ei ehkä ole käytetty sellaisenaan varhaismodernissa

\section{Kaavio 1}

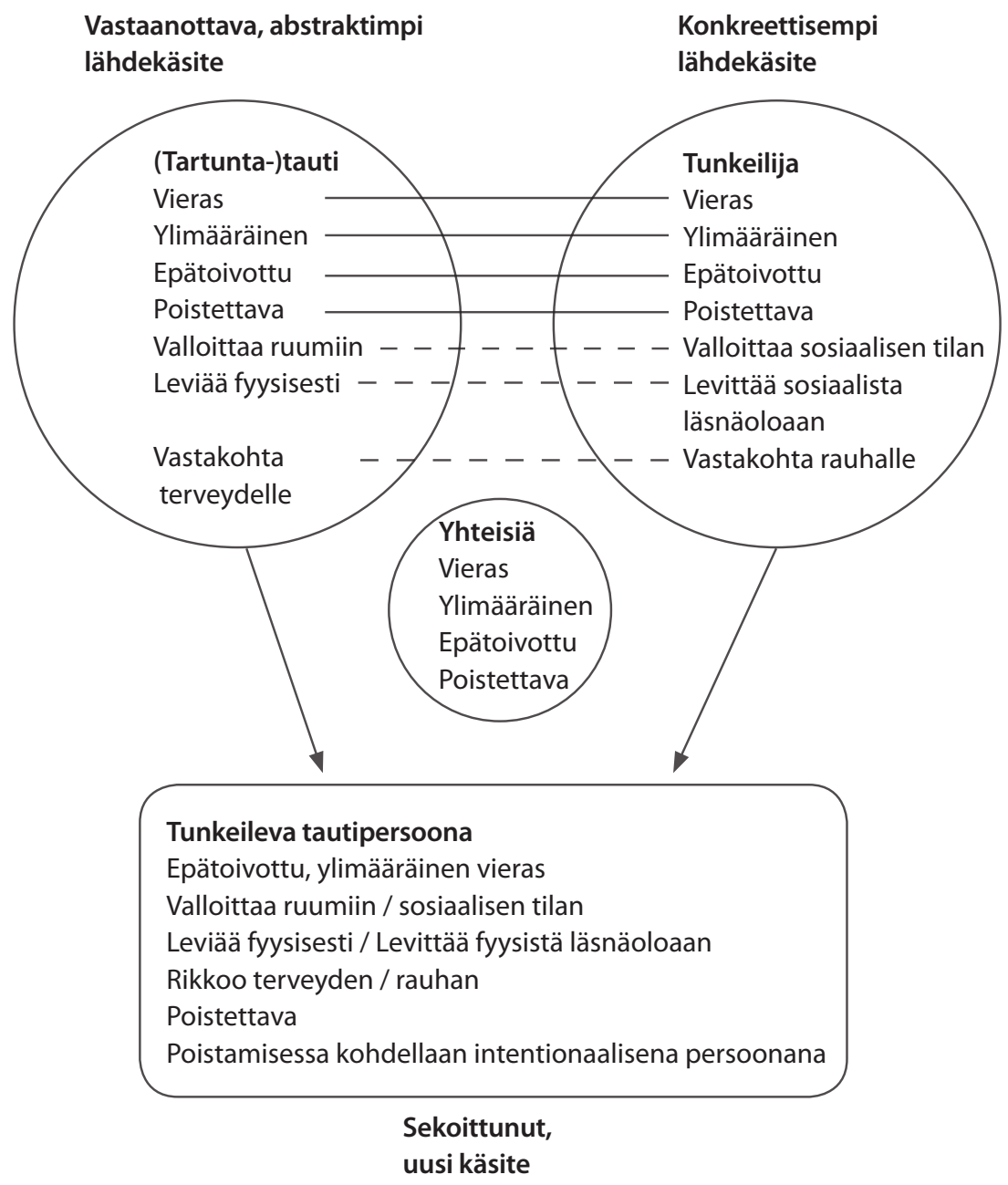

Elore (ISSN 1456-3010), vol. 25 - 1/2018. Julkaisija: Suomen Kansantietouden Tutkijain Seura ry. 
kielenkäytössä, mutta mielikuva tulee esiin erilaisista ohjeistuksista ja parannuskertomuksista, joissa korostetaan sitä, että taudinaiheuttaja tulee karkottaa ruumiista. Yhteisiä piirteitä taudin ja tunkeilijan käsitteille ovat vieraus, ylimääräisyys, epätoivottavuus ja poistettavuus. Sen lisäksi molempia määrittää joukko paralleelisia konsepteja: tauti/tunkeilija valloittaa ruumiin / sosiaalisen tilan, ja se leviää fyysisesti / levittää sosiaalista läsnäoloaan, ja lopulta se rikkoo terveyden / sosiaalisen rauhan. Tunkeilija viittaa myös intentionaaliseen persoonaan. Käsitteiden sekoittuessa myös tauti määrittyy tällä tavalla.

(Tartunta-)taudin ja tunkeilijan käsitteiden sekoittuminen perustuu yhteisten ja paralleelisten piirteiden huomattavaan määrään. Näistä kahdesta tauti toimii tässä epämääräisempänä käsitteenä kuin tunkeilija: ihmisen fyysinen olomuoto ja läsnäolo muuttuvat, eikä muutoksen vaikutusmekanismeista välttämättä ole tarkkaa tietoa. Sekoittuneen tauti on tunkeilija -käsityksen kautta muodostuu ymmärrettäväksi esimerkiksi se, miksi taudista ajatellaan, että siihen voi vaikuttaa sosiaalisin keinoin, esimerkiksi sanallisesti käskien. Ihmismieli tulkitsee tunkeilijan intentionaaliseksi tilaan astujaksi, jonka kanssa voi kommunikoida ja olla vuorovaikutuksessa, ja tämä käsitys siirtyy sekoittuneeseen käsitteeseen. ${ }^{6}$

Taudin ja tunkeilijan sekoittuminen näkyy esimerkiksi tautien karkotusloitsuissa. Oletetun haavoihin asettuvan vihat-taudin karkotusloitsuissa voidaan havaita taudin puhuttelua, joka näkyy muun muassa seuraavista esimerkeistä:

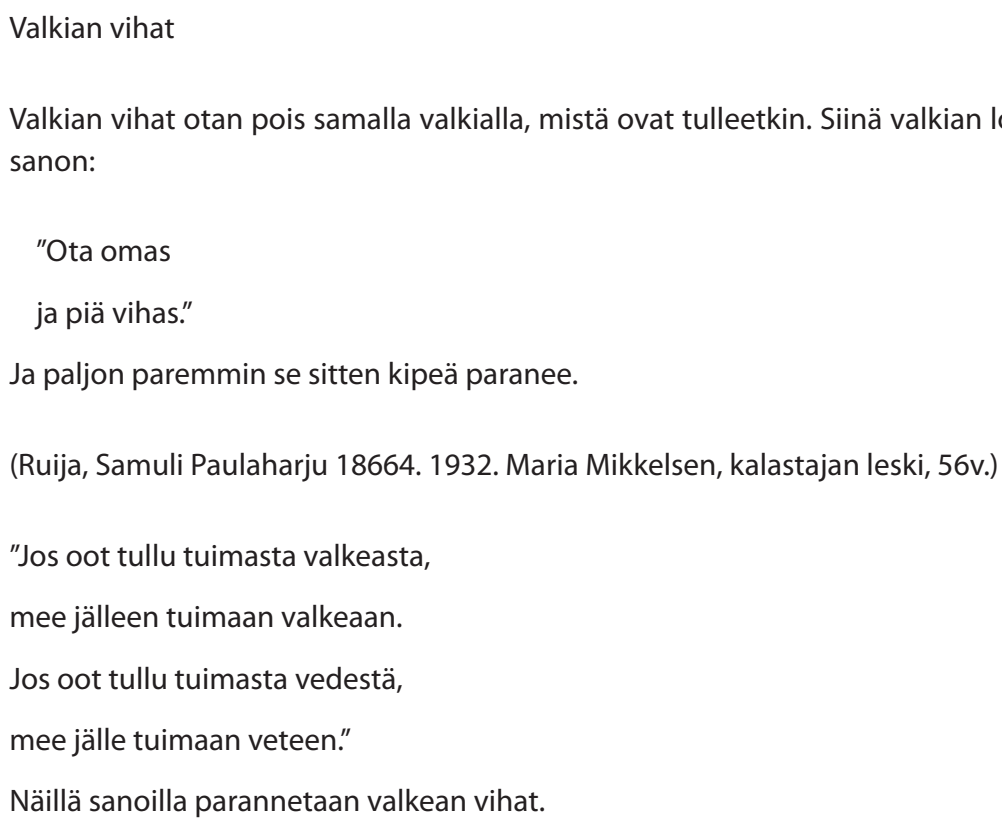

Ajatus siitä, että palohaavoihin voi asettua valkean tai tulen vihat -niminen tauti, implikoi että tämä tauti kykenisi aggressiotunteisiin. Kyseinen tautikäsitys saa myös uutta valoa käsitteellisestä sekoittumisesta ja tauti on tunkeilija -metaforasta. Tautioliota ei sekoittuneena

$6 \quad$ Pienempien tartuntatautien lisäksi myös esimerkiksi isorokkoa on personifioiden kutsuttu Aunuksessa Ospitš Ivanovitšiksi. Sairasta tuli taudin aikana kohdella kunnioittaen ja totellen, jotta tauti ei pahenisi (Hako 1957, 59). 
konseptina ajatella pelkästään vuorovaikuttavana tunkeilevana oliona, vaan sille tunnistetaan jopa hieman tunteita.

Maaginen ajattelu, kuten tarttumis- ja samankaltaisuusajattelu, on palautettavissa ihmismielen kognitiorakenteiden tuotoksiksi, jotka aktivoituvat tietyissä olosuhteissa. Parannusesimerkeissä esiintyviä maagisen ajattelun ilmenemismuotoja voidaan näin ollen tulkita myös kognitiotieteiden kautta. Psykologinen olemusajattelu ja käsitteellisen sekoittumisen teoria valottavat osaltaan sitä, miksi maagisella ajattelulla on varhaismodernissa suomalaisessa parannusperinteessä hyvin keskeinen asema. Tutkimuksessa voidaan myös kiinnittää enemmän huomiota siihen, mitkä kontekstipiirteet tekstiaineistojen taustalla aktivoivat maagista ajattelua. Tätä käyn läpi seuraavaksi apunani ritualisaation näkökulma.

\section{Ritualisoitunut käyttäytyminen ja sen aktivoituminen}

Suomalaisen parannusmagian voidaan tulkita sisältävän ritualisaatiota. Ritualisoitunutta käytöstä voidaan kuvata tietyissä tilanteissa toistuvana, strukturoituna ja päämäärähakuisena käyttäytymisenä, ja sen välttäminen näissä tilanteissa aiheuttaa ihmisessä usein ahdistusta (Boyer \& Liénard 2006). Tietyt elämänkaaren tapahtumat ovat usein ritualisoituneen käyttäytymisen ympäröimiä: esimerkiksi raskauteen ja lapsen syntymään tai läheisen kuolemaan liittyy ritualisaatiota. Ritualisoitunut käyttäytyminen ei kuitenkaan tarkoita samaa kuin rituaali, johon liittyy myös paljon kulttuurisia määritteitä. Yhtäläisyysmerkkien vetäminen kaiken magian ja ritualisoituneen käyttäytymisen välille on yhtä lailla ongelmallista. Suomalaisesta parannusmagiasta kertovissa aineistoissa voidaan kuitenkin havaita viitteitä ritualisoituneen käyttäytymisen vaikutuksista.

Pascal Boyerin ja Pierre Liénardin mukaan ritualisoitunut käyttäytyminen on sidoksissa tiettyihin teemoihin, jotka ovat evoluution aikana olleet merkittävimpiä uhkia ihmisten selviytymiselle ja suvunjatkamismahdollisuuksille, toisin sanoen uhkia omien geenien säilymiselle (Boyer \& Liénard 2006). Suurimpia uhkia inmislajin olemassaolon aikana ovat olleet riskit lisääntymiskelpoisuudessa, saalistus, taudinaiheuttajien tarttuminen, resurssien niukkuus ja sosiaaliset haitat (ibid., 602). Ihminen reagoi voimakkaammin näihin uhkiin kuin paljon myöhemmin kehittyneisiin uhkiin, esimerkiksi alkoholiin tai tupakkaan.

Jo Bronislaw Malinowski huomasi omassa trobriandi-tutkimuksessaan, että tietynlaiset elinkeinoelämän toiminnot liittyvät rituaalielämään, kun taas toiset eivät (Malinowski 1992). Trobriandi-heimon keskuudessa syvänmeren kalastukseen liittyi huomattava määrä rituaaleja mutta turvallisempaan laguunikalastukseen ei. Malinowski esitti tältä pohjalta, että rituaalit ehkäisisivät ahdistusta ja stressiä, joita vaarallisempi kalastusmuoto aiheutti.

Jesper Sørensen on täydentänyt Malinowskin päätelmää siten, että toisinaan rituaalisuus myös ylläpitää ahdistusta eikä ainoastaan lievennä sitä (Sørensen 2013). ${ }^{8}$ Hän esittääkin, että ritualisaatio ei liity pelkästään vaarallisten tilanteiden aiheuttaman ahdistuksen hallintaan, vaan sitä esiintyy ylipäätään lisääntymiskelpoisuutta uhkaavissa tilanteissa. Vaikka

7 Stark pitää myös nenä-tautia, esimerkiksi metsänneniä, vihojen kaltaisena tautina, jonka alkuperäksi on myös tulkittu luonnon voimien aggressiotunteet (Stark 2006, 269-271).

8 Boyer \& Liénard ehdottavat, että ritualisoitunut käyttäytyminen helpottaa lyhytkestoisesti uhkaan liittyvää ahdistusta mutta käyttäytymismallia säännöllisesti toistettaessa ahdistuksen helpottamisefekti pienenee (Boyer \& Liénard 2006, 607). 
ritualisaatio ei välttämättä poista ahdistusta, siitä voi olla muuta hyötyä. Ensinnäkin hallinnantunne rohkaisee jälleen uusiin, tärkeisiin mutta myös epävarmoihin toimintoihin, jotka onnistuessaan ylläpitävät elämää ja lisääntymismahdollisuuksia (Langer 1975; Wohl \& Enzle 2002; Wood \& Clapham 2005; Sørensen 2013, 239). Toisaalta rituaalinen toiminta epävarmoissa tilanteissa jakaa myös yksilöiden toimintavastuuta rituaaliin osallistuvalle ryhmälle ja rituaalille itselleen, mikä helpottaa ryhtymistä riskialttiisiin toimintoihin (Evans-Pritchard 1976; Sørensen 2013, 239).

Taudinaiheuttajien tarttumisen uhka, joka Boyerin ja Liénardin mukaan on ollut yksi evolutiivisesti merkittävistä uhkatekijöistä inmiselle, ilmenee varhaismoderneissa suomalaisissa palohaavojen parannusaineistoissa mielenkiintoisella tavalla. Ihon palamiseen on aiemmin liittynyt paljon voimakkaammin tarttumisajattelu kuin esimerkiksi 2000-luvulla, ja tulen vihat on mielletty nimenomaan tarttumisuhaksi.

Tulen vihat.

Ennen jos oli joku kipiä ihmisellä, niin sitä ei saanut viedä tulen näkyviin eikä saunaan, sanottiin, että siihen käypi tulen vihat, ja kun joku sellainen paha vieras sattui talossa käymään, niin sen pois lähtiessä mentiin ja heitettiin tulisia hiiliä ja tuhkaa perästä. - Tuossa meidän naapurissa oli Kukkulan mummo, se heitti vielä sen tuhkankin takakättänsä, itse katsoi eteenpäin, ja taaksensa heitti ja sanoi: "Tuhkaa katein katsovalle ihmiselle!"

(Kuhmoinen. Ulla Mannonen 11548. 1940. Ida Mustonen 64v.)

Tässä esimerkissä kertoja korostaa, että tulen vihat voivat tarttua tulesta tai kuumasta kipeään paikkaan. Vihoja pidetään myös kateina, toisten ihmisten aiheuttamina harmeina. Myös tässä tapauksessa kertoja implikoi, että vihat voivat tarttua vierailijasta pelkän läsnäolon perusteella. Vihojen näkeminen tartunnaisina, evolutiivisesti merkittävänä uhkana, voi osaltaan selittää sitä, miksi palohaavojen parantamisesta on olemassa lukuisasti aineistoa arkistoituna, ja toisaalta myös sitä, miksi jopa pieniin palohaavoihin ehdotetaan aineistoissa voimakkaana pidettyä, rituaalista loitsuparannusta. Tartunnaisuhka herättää inmiset kaipaamaan ritualisoituneita poistotoimenpiteitä karkotusloitsuineen, kuten myös yllä olevan esimerkin lyhyestä loitsusta käy ilmi.

Boyer \& Liénard esittävät (2006), että ritualisoituneen käytöksen yleisiä ominaispiirteitä olisivat seuraavat: 1) Pakonomaisuus. Toiminnan tekemättä jättäminen tuntuu ihmisistä vaaralliselta, epäsopivalta tai turvattomalta, vaikka ihmisillä ei olisikaan selkeitä ajatuksia siitä, mitä tekemättä jättämisestä seuraisi. 2) Struktuurista kiinnipitäminen. Toimintaa pyritään suorittamaan tavalla, joka noudattaa inmisten mielikuvia siitä, miten toiminta on aina ennenkin suoritettu. 3) Toiminnan päämäärän epäselvyys. Toiminnan päämäärä ei ole se, mitä intuitiivisesti tai arkikontekstissa pidettäisiin päämääränä. 4) Toiminnan sisäinen toistuvuus. Toimintaan kuuluu toistettavia toimintoja tai liikkeitä, ja toistojen määrä on oleellista toiminnan kannalta. 5) Toiminnan liittyminen teemoihin. Toiminta liittyy esimerkiksi seuraaviin teemoihin: saastuminen ja puhdistautuminen, vaara ja suojautuminen tai muiden tunkeutuminen omalle alueelle ja järjestetyn ympäristön luominen. Boyerin ja Liénardin teoretisoinnin mukaan käyttäytymisen ritualisaatioon liittyy samoja mekanismeja kuin pakkoneuroosienkin muodostumiseen. 
Parantamistilanteella on näennäisesti selkeä päämäärä: sairaan tai vammautuneen ihmisen tekeminen terveeksi. Myös parannustilanteen toimintamallien tarkkaa noudattamista voidaan perustella sillä, että toiminnon on todettu aiheuttavan paranemista, joten sen noudattamiselle on selkeät syyt. Monissa varhaismoderneissa palohaavojen parannuskertomuksissa tai -ohjeistuksissa on kuitenkin myös havaittavissa Boyerin ja Liénardin muotoilemia ritualisoituneen käyttäytymisen ominaispiirteitä. Näitä voidaan tarkastella seuraavasta esimerkistä:

\begin{abstract}
Valkean vihojen poistaminen
Valkean vihat poistettiin seoksella, joka oli tehtävä tinanappoon: suolaa, vettä ja tuhkaa kolmesta tulisijasta. Tuhkan piti olla niin kuumaa, että se veteen pantaessa kärähti. Seosta oli ensiksi pantava vähän suuhun, ettei "palo painu syvälle", vasta sen jälkeen voideltava palanut paikka. Lopuksi oli heitettävä vettä kerran vaseman olkapään yli.
\end{abstract}

(Kyyjärvi. F. A. Luukko 132. 1932.)

Sitä, kuinka pakonomaisena kertoja pitää esittämäänsä toimintamuotoa, voidaan arvioida tekstimuodon perusteella. Ohjeistuksen verbirakenteet ovat nesessiivisiä eli ilmaisevat velvoittavuutta tai suositeltavuutta (oli tehtävä, oli pantava, oli voideltava). Toisaalta tällainen verbirakenne on saattanut olla vain tyypillinen ohjeiden kertomisen muoto. Myös tarkkojen yksityiskohtien mainitseminen viittaa siihen, että näiden yksityiskohtien noudattamisella olisi kertojan mukaan merkitystä (esim. astiana tinanappo, tietynlainen tuhka, voiteen käyttöjärjestys, vasemman olkapään ylitys). Kertoja ei eksplisiittisesti mainitse, että tällainen parannustapa tulisi toteuttaa aina täsmälleen samalla tavalla, mutta verbimuoto ja yksityiskohtien mainitseminen viittaavat kyllä siihen.

Esimerkistä voidaan havaita myös kohtia, joissa yksittäisen toiminnon suhde päämäärään, paranemiseen, on intuitiivisesti epäselvä. Haavalle laitetaan suolavettä, vaikka se kirvelee. Palohaava on ulkoinen, mutta sitä lääkitään sisäisesti. Toiminnoille annetaan ainoastaan yleispätevä päämäärä ja abstrakti tai symbolinen selitys. Tässä kohtaa on kuitenkin huomioitava myös, että nykytutkijan arkikokemukset kotitalouden tarvikkeista, kotoisista toiminnoista tai terveys- ja sairauskäsityksistä eivät ole samat kuin varhaismodernien suomalaisten vastaavat arkikokemukset. Intuitiivisuuden tai epäintuitiivisuuden määritteleminen on siis tehtävä varoen.

Boyerin ja Liénardin mallin viimeiset kohdat, toiminnan sisäinen toistuvuus sekä liittyminen teemoihin, näkyvät tässä esimerkissä selkeimmin. Parannusseokseen tulee kertojan mukaan saada tuhkaa kolmesta eri tulipesästä - yksi ei riitä. Parannustoiminnot ovat myös sidoksissa saastumisen ja tarttumisen sekä niistä puhdistautumisen teemaan.

Käyttäytymisen ritualisoitumisen teorian avulla voidaan tulkita, miksi ihmiset lähtevät muodostamaan monimutkaisia ja strukturoituja toimintamuotoja esimerkiksi palohaavoja parannettaessa, kun arkikokemuksen mukaan (2000-luvulla mutta todennäköisesti myös 1900-luvun alussa) jo kylmän pitäminen palohaavan päällä sekä arven rasvaaminen auttavat 
palohaavoja paranemaan. ${ }^{9}$ Teoria valottaa ihmismielen liikkeitä, ei vain modernisoituneessa kaupunkikontekstissa vaan myös historiassa.

Palohaavojen parannustavat ovat toisinaan muotoutuneet ritualisoituneeksi käytökseksi, koska tällainen toiminta on ihmiselle tyypillistä tietyissä olosuhteissa. Tarkastelemassani palohaavojen parannuskontekstissa olosuhteisiin on vaikuttanut merkittävästi se, miten palohaavat on käsitetty: niiden yhteyteen on tulkittu tarttumisuhka, tulen vihat, joka herättää ihmisessä evolutiiviseen selviämiseen liittyviä reaktioita.

Oletettavaa on, että varhaismodernissa Suomessa myös muissa taikojenharjoittamiskonteksteissa olisi havaittavissa ritualisoitunutta käyttäytymistä. Olisi mielekästä tarkastella myös sitä, kuinka olosuhteet vaikuttavat näissä tilanteissa. Voidaanko lemmentaikoihin liittää inmisen taipumus ylläpitää lisääntymiskelpoisuuttaan? Vaikuttavatko vaaralliseen saalistukseen liittyvät metsästystaiat ritualisoituneemmilta kuin esimerkiksi kalastustaiat? Tällaisiin kysymyksiin vastaaminen auttaisi muotoilemaan sitä, missä kohtaa suomalaisten taikaperinteiden biologiset taustat loppuvat ja mistä kulttuuriset vaikutteet alkavat.

\section{Yhteenveto}

Olen tässä katsausartikkelissa esittänyt erilaisia kognitiivisia ja evoluutiopsykologisia lähestymistapoja magian tutkimukseen. Tällaisten teorioiden hyödyntäminen historiallisten magiaperinteiden tutkimuksessa vastaa uudesta näkökulmasta muun muassa seuraaviin kysymyksiin: Miksi magiaa harjoitettiin? Miksi se tuntui velvoittavalta? Miksi maagiset toimenpiteet rakentuvat niin kuin rakentuvat?

Maaginen ajattelu ja magian harjoitus ovat inmisille tyypillisiä toimintatapoja olosuhteissa, joissa elämä, terveys, selviytyminen ja lisääntyminen ovat uhattuina. Suomalaisessa magiaperinteessä näkyy paljon sitä, kuinka tietyt ajattelutavat ja käyttäytymismallit ovat muovautuneet ihmiselle oleellisiksi elämän ja sen ylläpitämisen kannalta. Magia ja maaginen ajattelu, joka ohjaa käytännön magian rakentumista, ovat olleet keinoja käsitellä evolutiivisesti merkittävien uhkakuvien synnyttämää ahdistusta. Ahdistukseen liittyvät myös sellaiset emootiot kuin viha ja pelko, joiden myös esimerkiksi Stark (2016) on havainnut liittyvän magian harjoittamisen perusteluihin. Stark on tarkastellut, kuinka viha ja pelko saavat kulttuurisesti omaleimaisia ilmenemismuotoja suomalaisen magiaperinteen piirissä, mutta ihmisen emootioina ne ovat kuitenkin universaaleja, eivät kulttuurilähtöisiä.

Kognitiivinen lähestymistapa magian tutkimukseen tarkastelee sitä, millainen on se ihmisen mieli, joka kulttuurisessa kontekstissa tuottaa esimerkiksi maagisia toimenpiteitä, maagista ajattelua tai sanallisia representaatioita magiasta. Suomalaisen varhaismodernin magian tutkimuksessa olisi mielenkiintoista hyödyntää laajemmin mielen prosessien tai käyttäytymisen ritualisaation näkökulmia, ja toisaalta samoja teorioita voi hyödyntää myös nykyperinteiden tutkimukseen esimerkiksi uushengellisten ryhmien parissa. Ymmärtämällä mielen toimintaa voimme ymmärtää paremmin myös sen tuottamia ilmiöitä.

9 Suomalaisen Kirjallisuuden Seuran perinteen ja nykykulttuurin kokoelman kansanläkintäkortistossa on verrattain vähän ohjeistuksia siitä, että palohaavaa hoidettaisiin kylmällä. Kylmän tärkeys näkyy kuitenkin palohaavojen parannusloitsuissa, joissa oleellisena osana ovat esimerkiksi pakkasen sanat. Erilaisia voiteita ja rasvoja mainitaan parannustarpeiksi varsin säännöllisesti niin parannusohjeissa ja -kertomuksissa kuin loitsuteksteissäkin ("mehiläinen tuo voiteita" -teema). 


\section{Lähteet}

Suomalaisen Kirjallisuuden Seuran perinteen ja nykykulttuurin kokoelma.

\section{Kirjallisuus}

Boyer, Pascal \& Pierre Liénard 2006: Why ritualized behavior? Precaution systems and action parsing in developmental, pathological and cultural rituals. - Behavioral and Brain Sciences 29: 595-650.

Durkheim, Émile 1965: The Elementary forms of the religious life. Transl. J. W. Swain. New York: George Allen \& Unwin.

Evans, Jonathan St. B. T. 2010: Thinking twice: Two minds in one brain. Oxford: Oxford University Press.

Evans-Pritchard, Edward E. 1976: Witchcraft, oracles and magic among the Azande. Oxford: Oxford University Press.

Fauconnier, Gilles 1994: Mental spaces: Aspects of meaning construction in natural language. Cambridge: Cambridge University Press.

Fauconnier, Gilles 1997: Mapping in thought and language. Cambridge: Cambridge University Press.

Fauconnier, Gilles \& Mark Turner 2002: The way we think: Conceptual blending and the mind's hidden complexities. New York: Basic Books.

Frazer, James 1929. The golden bough: A study in magic and religion, vol. 1. 3rd edn. London: Macmillan. [1911]

Freud, Sigmund 1981a: Obsessive actions and religious practice. - The standard edition of the complete psychological works of Sigmund Freud. vol. IX. Translated from the German under the general editorship of James Strachey. London: Hogarth Press. 115-127.

Freud, Sigmund $1981 \mathrm{~b}$ :Totem and taboo. - The standard edition of the complete psychological works of Sigmund Freud. vol. XIII. Translated from the German under the general editorship of James Strachey. London: Hogarth Press. 1-162.

Gelman, Susan. A., John D. Coley \& Gail M. Gottfried 1994: Essentialist beliefs in children: The acquisition of concepts and theories. - Hirschfeld, Lawrence A. \& Susan A. Gelman (eds.), Mapping the mind. Domain specificity in cognition and culture. Cambridge: Cambridge University Press. 341-365.

Grimes, Ronald L. 2014: The craft of ritual studies. Oxford: Oxford University Press.

Hako, Matti (toim.) 1957: Kansanomainen lääkintätietous. Helsinki: SKS.

Honko, Lauri 1960: Varhaiskantaiset taudinselitykset ja parantamisnäytelmä. - Hautala, Jouko (toim.), Jumin keko. Tutkielmia kansanrunoustieteen alalta. Helsinki: SKS. 43-111.

Issakainen, Tenka 2012: Tavallista taikuutta. Tulkinta suomalaisten taikojen merkityksistä Mikko Koljosen osaamisen valossa. Turun yliopisto.

Kahneman, Daniel 2011: Thinking, fast and slow. London: Allen Lane. 
Krohn, Kaarle 2008: Suomalaisten runojen uskonto. Suomensuvun uskonnot. Helsinki: Salakirjat. [1915]

Lakoff, George \& Mark Johnson 1980: Metaphors we live by. Chicago: University of Chicago Press.

Langer, Ellen J. 1975: The illusion of control. - Journal of personality and social psychology 32(2): 311-328.

Lévy-Bruhl, Lucien 1985: How natives think. Princeton: Princeton University Press.

McCauley, Robert N. 2011: Why religion is natural and science is not. Oxford: Oxford University Press.

Malinowski, Bronislaw 1935: The coral gardens and their magic. Vol 1 \& 2. London: George Allen \& Unwin Ltd.

Malinowski, Bronislaw 1992: Magic, science and religion and other essays. Prospect Heights: Waveland Press Inc.

Marett, Robert R. 1979: The threshold of religion. New York: AMS Press.

Mauss, Marcel 1972: A general theory of magic. Transl. Robert Brain. London: Routledge \& Kegan Paul.

Medin, Douglas L. 1989: Concepts and conceptual structure. - American psychologist 44(12): 1469-1481.

Nemeroff, Carol \& Paul Rozin 1994: The contagion concept in adult thinking in the United States: Transmission of germs and of interpersonal influence. - Ethos 22(2): 158-186.

Nemeroff, Carol \& Paul Rozin 2000: The makings of the magical mind. The nature and function of sympathetic magical thinking. - Rosengren, Karl S., Carl N. Johnson \& Paul L. Harris (eds.), Imagining the impossible. Magical, scientific and religious thinking in children. Cambridge: Cambridge University Press. 1-34.

Otto, Bernd-Christian \& Michael Stausberg (eds.) 2013: Defining magic. A reader. London: Routledge.

Otto, Bernd-Christian \& Michael Stausberg 2013: General introduction. - Otto, BerndChristian \& Michael Stausberg (eds.), Defining magic. A reader. London: Routledge. 1-14.

Piela, Ulla 1983: Muuttumaton tautiloitsu? - Laaksonen, Pekka \& Ulla Piela (toim.), Kansa parantaa. Helsinki: SKS. 242-252.

Piela, Ulla 1989: Loitsut 1800-luvun Pohjois-Karjalassa. - Knuuttila, Seppo \& Pekka Laaksonen (toim.), Runon ja rajan teillä. Helsinki: SKS. 82-107.

Pohjanheimo, Outi 2012: The enrichment of magical thinking through practices among Reiki self-healers. - B. Dahla (ed.), Post-secular religious practices. Scripta Instituti Donneriani Aboensis. Åbo: The Donner institute for research in religious and cultural history. 289-313.

Rozin, Paul, Linda Millman \& Carol Nemeroff 1986: Operation of the laws of sympathetic magic in disgust and other domains. - Journal of personality and social psychology 50(4): 703-712.

Rozin, Paul, Carol Nemeroff, Marcia Wane \& Amy Sherrod 1989: Operation of the sympathetic magical law of contagion in interpersonal attitudes among Americans. - Bulletin of the Psychonomic Society 27(4): 367-370. 
Rozin, Paul \& Carol Nemeroff 1990: The laws of sympathetic magic: A psychological analysis of similarity and contagion. - Stigler, James W., Richard A. Shweder \& Gilbert Herdt (eds.), Cultural psychology. Essays on comparative human development. Cambridge: Cambridge University Press. 205-232.

Siikala, Anna-Leena 1992: Suomalainen šamanismi. Mielikuvien historiaa. Helsinki: SKS.

Stark, Laura 2006: The magical self. Body, society and the supernatural in early modern, rural Finland. Helsinki: Suomalainen Tiedeakatemia.

Stark, Laura 2016: Emotional causality in dynamistic Finnish-Karelian folk belief. Scandinavian journal of history 41(3): 369-387.

Sørensen, Jesper 2007: A cognitive theory of magic. Lanham: AltaMira Press.

Sørensen, Jesper 2013: Magic reconsidered: Towards a scientifically valid concept of magic. - Otto, Bernd-Christian \& Michael Stausberg (eds.), Defining magic. A reader. London: Routledge. 229-242.

Tambiah, Stanley J. 1968: The magical power of words. - Man 3: 175-208.

Turner, Mark 1996: The literary mind. Oxford: Oxford University Press.

Tylor, Edward B. 1977: Primitive culture: Researches into the development of mythology, philosophy, religion, art, and custom, vols. 1 \& 2. New York: Gordon Press. [1871]

Wegner, Daniel M. 2002: The illusion of conscious will. Cambridge: The MIT Press.

Wohl, Michael J. A. \& Michael E. Enzle 2002: The deployment of personal luck: Sympathetic magic and illusory control in games of pure chance. - Personality and social psychology bulletin 28(10): 13-88.

Wood, W. Scott \& Maria M. Clapham 2005: Development of the drake beliefs about chance inventory. - Journal of gambling studies 21(4): 411-430.

TM Siria Kohonen on folkloristiikan jatko-opiskelija Helsingin yliopistossa. Hän valmistelee väitöskirjaa varhaismodernin ajan suomalaisista parantamiskäytännöistä ja niiden taustalla vaikuttavista kognitiivisista prosesseista. 